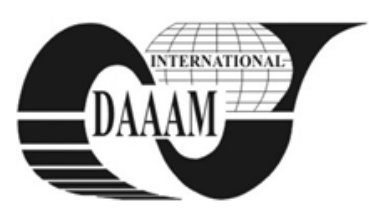

Annals of DAAAM for 2011 \& Proceedings of the 22nd International DAAAM Symposium, Volume 22, No. 1, ISSN 1726-9679 ISBN 978-3-901509-83-4, Editor B. Katalinic, Published by DAAAM International, Vienna, Austria, EU, 2011 Make Harmony between Technology and Nature, and Your Mind will Fly Free as a Bird Annals \& Proceedings of DAAAM International 2011

\title{
MODELS FOR MARKET STRUCTURE
}

\section{BULEARCA, M[arius]; SERBAN, C[laudia] E[lena]; MUSCALU, M[ihai] - S[abin]; VASILE, C[ristina] M[ioara] \& POPESCU, C[atalin]}

\begin{abstract}
Market imperfections are usually called "best friends of conservatism in research", and that is why we decided to analyze the existence of industrial monopolies. We proved how their existence is affecting depletion rates and thus the cost/price ratio of fossil fuels and mining products.
\end{abstract}

Key words: natural resources, mining industry, profit trend, cartel, market, perfect competition

\section{INTRODUCTION}

Economic analysis of extractive industry is fundamentally different from the analysis of agriculture, manufacturing and services. The main reason is that the mineral resources are exhaustible resources. In other words, in mining industry an initial stock of reserves will exhaust in time. Consequently, if we start from the premise that the owner of a resource, like any other owner, is seeking for maximum gain, we must take into consider multiple factors, unique in the mining industry.

Until now, economic analysis in general, and especially that related to the natural resources market, has been characterized by the concept of natural resource scarcity, much of the methodological concepts being closely related to resources allocation problems at micro and macro-economic level.

Based on these considerations, it should be noted that in the economic literature, the idea of resource reserves depletion has been often accredited to the extent of economic and demographic development.

One of the objectives of this research is to examine the optimal level of extraction of non-renewable mineral resources in terms of government which wants to maximize social welfare by exploiting these resources.

\section{MARKET STRUCTURE AND NATURAL RESOURCES EXPLOITATION}

Often it had been discussed the fact that market imperfections, especially if highly monopoly, are "best friends of conservatism", says Hotelling (1931). Should be emphasized that monopoly can exist in mining industry as in manufacturing industry, affecting depletion rates and thus the cost/price of fossil fuels and mining products.

In this sense, arises the question in what ways a monopolistic behavior may differ from a perfectly competitive behavior in the mining industry. It should be recalled again that the objective of any business is the same, that is extraction of resources in a manner which to maximize the present value of profits over time. When this happens, the market rate of return will be one of the determinants of firms both monopolistic, and perfectly competitive firms. This is inherent in the economic fundamental principle (Hartwick \& Olewiler, 1986).

First, suppose that a monopolist owner is the sole owner of a set stock that he can extract at zero cost. Market demand curve, the monopolist owner must cope with, remains stationary in time. His problem is to find an extraction scheme to bring maximum profits discounted over time until all original stock (inventory) is depleted over time. Its marginally income "MR" increase from two consecutive moments of time will be:

$$
\frac{M R(t+1)-M R(t)}{M R(t)}=r
$$

that is the percentage change in marginal revenue equals the time rate of profit, " $r$ ", meaning that in every moment of time monopolist owners' marginal revenue amounts to the market rate of return.

In Fig. 1 is represented the situation in which production in each moment of time met conditions in equation (1). In Fig. 1(a), an output level at time $t$, " $Q_{t}$ ", corresponds to the price level, " $\mathrm{P}_{\mathrm{t}}$ ". In the next period, $\mathrm{t}+1$, price, and thus marginal revenue, must increase linearly with the market rate of profit, which may be obtained only by reducing production, namely $Q_{t+1}<Q_{t}$.

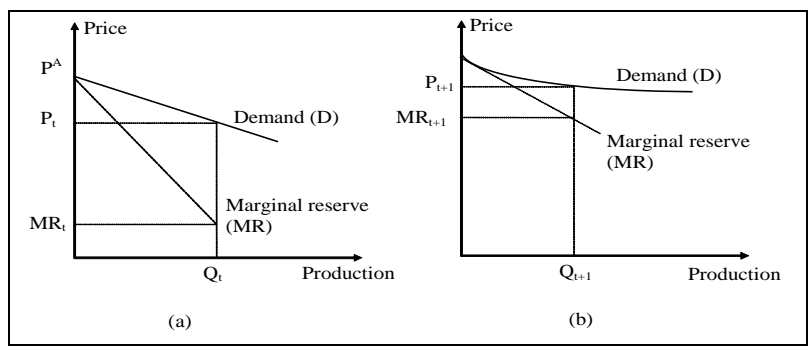

Fig. 1. Stock depletion in monopolistic situation, with (a) time $=\mathrm{t}$, and $(\mathrm{b})$ time $=\mathrm{t}+1$

When marginal revenue is discounted to market rate of profit, it is the same in different time periods (Kula, 1994). Last unit of extracted production will produce the highest undiscounted marginal income, which corresponds to the price limit "p*".

As the monopolist owner shifts upward the marginal revenue curve, traders that are competing on mining markets, very many on the market, will shift upward the demand curve every moment of time. In both market structures, the economic fundamental principle must meet the same profit rate.

Since the marginal revenue curve is steeper than the demand curve, that is slope $M R>$ slope $D$, then the monopolist owner will have to decrease production less than competing firms, each moment of time. Thus, the monopolist owner will use its reserves more slowly than firms existing on the competitive market.

Because the initial production of the monopolist owner is lower than those in competition, under the condition of two different price trends in both markets, then its initially price must be higher. Because marginal revenue is less than the price (see Fig. 2), monopolist price trend will be flatter than the competitive price, meaning that the price is growing more slowly. 
In the monopolistic situation, the initial prices are higher, but their growth rate is lower. Assuming there is no change in demand for natural resources, then, in the monopolistic situation the reserve stocks will last for a longer time period compared to competition in the extractive industry (Samuelson \& Nordhaus, 1992).

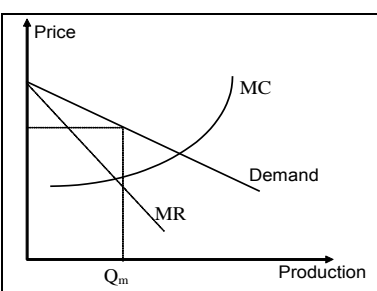

(a)

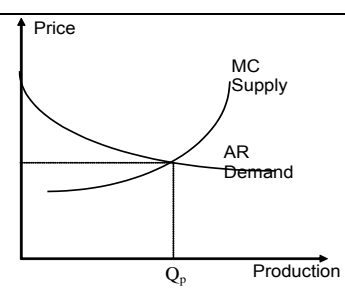

(b)
Fig. 2. Price and production levels in mining industry, with (a) monopoly, and (b) perfect competition

It was stressed that when depletion time $(\mathrm{T})$ is long, then many changes can occur related to natural resource extraction technology and their use, which will affect the demand curve. It can be argued that as long as the competitive market prices are growing fast, this situation will encourage the users of these resources to seek new sources of alternative raw materials (Barnett, 1979).

In a monopolistic situation, however, demand for natural resources, raw materials for manufacturing industry cannot be avoided as long as their users are getting familiar to the slow growth of resource prices and thus will maintain their constant demand. With a constant demand, the ultimate depletion will take place in the competitive market, and if users gradually pass to substitutes, it is possible some of the stock of reserves to remain in deposits (Wonnacott \& Wonnacott, 1986).

It is also inherent in our previous assertion that monopoly rent, which includes both the resource rent and excess profits, exceeds the resource rent obtained in the competitive market. It is therefore understandable why independent owners of natural resources are willing to form a cartel where they believe that may manifest as a collective monopoly.

Indeed, a cartel is a group of independent owners who are trying, by common understanding, to act as a firm. In a cartel case, each owner agrees to produce less than they would produce under competitive market conditions. The expected effect of the cartel is to increase the market price so that producers can earn excess profits.

In Fig. 3 are shown the production levels both in competitive market and in terms of a cartel. To simplify the calculations let's assume that we analyze the case of a zero rate of profit (Pearce, 1983). Fig. 3(a) provides competitive price " $0 \mathrm{P}_{\mathrm{p}}$ " and production competition " $0 \mathrm{Q}_{\mathrm{p}}$ " by intersecting supply and demand curve. A competitive market firm believes the market price as given and produce at a level where price equals marginal cost, which then becomes the marginal revenue and schedules its own production at this level. Its market segment covers only part of its total sales.

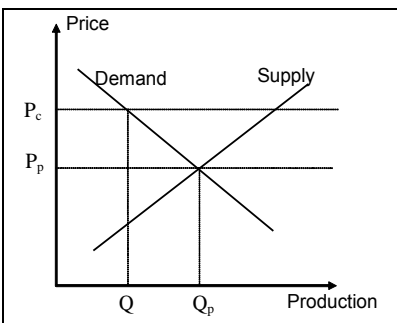

(a)

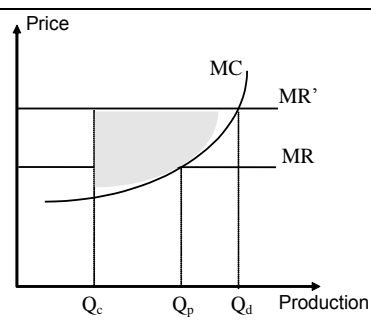

(b)
Fig. 3. Incentives "to deceive" in terms of cartel, with (a) perfect competition, and (b) monopoly
Suppose now that to achieve excess profits all competing firms would join together to form a cartel. In this case, their production "0Q" would fall so that market prices are rising to " $0 \mathrm{P}_{\mathrm{c}}$ ". Note that the ability to offer is not diminishing as production level reduces artificially. To each cartel firm is given such a share so that the reduced rate of production on the market can be maintained. Individual company depicted in Fig. 3 (b) is told to reduce production at " $0 \mathrm{Q}_{\mathrm{c}}$ " (Home, 1979).

In this new situation created there is a great temptation "to deceive". Individual company, by reducing its price just a little (slightly below the cartel price), may sell more, "0Q $\mathrm{Q}_{\mathrm{d}}$ ", at the same expenses as other members. For production " $0 \mathrm{Q}_{\mathrm{d}}$ ", the firm's marginal cost equals the new marginal revenue, "MR"”, and shaded area shows over-excess profit that can be achieved "through cheating" the cartel.

\section{RESULTS}

To conclude this analysis, we must point out that a cartel may increase prices only by reducing its production. However, at higher prices, members forming a cartel are tempted to produce even more than when the competitive market equilibrium. As the cartel situation has more success, the temptation "to deceive" will tend to grow.

Therefore in order to be successful a cartel requires some measures of domestic policy group to ensure that each member takes care of its own control share. In regards to natural resources depletion, for a cartel, the amount extracted at all points in time will be less than in the competitive situation, otherwise reserve stocks will get blocked in deposits.

Hence, the researches undertook in this paper stress out that natural resource market involves a comprehensive analysis according to several criteria: requirements of economic growth, future potential of environmental factors, scientific and technological progress and demographic change; these factors affect both demand and supply rate, as well as substitution rates, specific consumption rate reduction, etc.

The economic literature contains a comprehensive analysis of most of the aforementioned issues, which is why in this paper we shall dwell only on the following matters: limited character and scarcity of natural resources (supply) in relation to the development of demand; mechanisms and economic laws that describe the supply-demand ratio of natural resources determined by economic and social factors.

\section{REFERENCES}

Barnett, H. (1979). Scarcity and growth revisited, In: Scarcity and Growth Reconsidered (editor: V. K. Smith), Johns Hopkins University Press, ISBN 0801862310, Baltimore.

Hartwick, J.M. \& Olewiler, N.D. (1986). The Economics of Natural Resource Use, Harper \& Row, ISBN 978-960-474253-0, New York

Home, C.N. (1979). Natural Resources Economics, Issues, Analysis and Policy, Wiley, ISBN 978-0-470-72395-1, New York.

Hotelling, H. (1931). The Economics of Exhaustible Resources, In: Journal of Political Economy 39, ISBN 9780192820808, London

Kula, E. (1994). Economies of Natural Resources, the Environment and Policies, Second Edition, Chapman and Hall, ISBN 978-960-474-253-0, London

Pearce, D.W. (1983). Cost-benefit Analysis, Second Edition, MacMillan, ISBN 0333120639, London

Samuelson, P.A. \& Nordhaus, W.D. (1992). Economics, 14-th Edition, McGraw Hill Book Co., ISBN 0-07-1180648, New York

Wannacott, P. \& Wannacott, R. (1986). Economics, Third Edition, McGraw Hill Co., ISBN 0393970833, New York 